\title{
A TROUBLESOME RECURRENCE
}

\section{Racialized Realities and Racist Reasoning Today}

\author{
Lawrence D. Bobo \\ Department of African and African American Studies and Department of Sociology, \\ Harvard University
}

In a recent panel discussion at Harvard University's Hiphop Archive and Research Institute, Ferguson Activist Ashley Yates blasted the calls for a "politics of respectability" heard in some quarters after strident protests against police killings of unarmed Black civilians. She declared: "You can't pull your pants up high enough to stop a bullet!" Posing neatly coiffed and politely asking others to acknowledge one's humanity seems out of place in the face of circumstances, now numbingly catalogued in an exhaustive Department of Justice Report, that can only be described as modern state-sanctioned racial oppression (U.S. Department of Justice 2015). Sometimes outrage is justified. When deeply troublesome circumstances or events occur it is only natural that powerful responses should be expected to follow.

How should scholars and intellectuals respond when scientific racism seems to again rear its ugly head? The distinguished historian George M. Fredrickson warned in his book Racism: A Short History (2002): "The legacy of the past racism directed at blacks in the United States is more like a bacillus we have failed to destroy, a live germ that not only continues to make some of us ill but retains the capacity to generate new strains of a disease for which we have no certain cure" (p. 143). There is perhaps no more telling indicator of the truth of this anxiety-arousing observation than the resurgence of racial thinking taking place in connection with the mapping of the human genome and developments in biological science. This trend reached a new nadir with the publication of journalist and former New York Times science editor Nicholas Wade's recent book A Troublesome Inheritance: Genes, Race and Human History (2014). The book advocates not only for a biological understanding of race and racial differences, but attaches ostensible natural categorizations to profound differences between the races in contributions to the advancement of human civilization.

Fortunately, two eminent scholars of the place where race, scientific thinking, and social dynamics intersect provide careful and trenchantly reasoned reviews of this most troublesome book. Both Ann Morning and Dorothy Roberts find fault with Nicholas Wade's overt embrace of a biologically rooted racial categorization scheme. Both point out the inescapably political character and potential consequences of such a declaration, all of Wade's disclaimers to the contrary notwithstanding. Both reviewers are

Du Bois Review, 12:1 (2015) 1-4.

(C) 2015 Hutchins Center for African and African American Research 1742-058X/15 \$15.00

doi:10.1017/S1742058X15000077 
deeply troubled by Wade's failure to acknowledge the unambiguously rapacious and violent character of European empire building and colonialism or the deeply etched, long-term effects the wounds of colonial subjugation left on much of the "global south" into the present. The recrudescence of biological racism of the sort represented by Wade, however, cannot be taken lightly by serious scholars. It is important to engage and de-bunk work so openly tethered to a racialist project, identify its many weaknesses, and remain on continuous alert to the potentially troublesome turn of elite social thinking that it may represent.

Also in this issue, political theorist Sharon Stanley takes on the difficult challenge of how to actually achieve integration. In a densely reasoned analysis, Stanley helps to sharpen the analytical and practical distinctions between Jim Crow segregation, desegregation, racial imbalance, and integration. The essay calls for a more explicit and analytically rigorous understanding of what genuine integration would entail. She stresses that without such clarity the legal and political project of full membership in the polity for marginalized groups is likely to continue to stall.

Andrew J. Douglas offers another exposition on political theory, in this case conjuring W. E. B. Du Bois's critique of the market economy. Douglas suggests that a potentially noteworthy continuity in the writings of Du Bois over the long arc of his career as social scientist, scholar, activist, and public intellectual was skepticism about liberal free market logic and values in a context of deeply entrenched White privilege and Black marginalization. Indeed, Du Bois signaled an enduring concern precisely with the interplay of Black poverty and anti-Black prejudice in his immortal work The Souls of Black Folk, writing in 1903 that the Negro "felt his poverty; without a cent, without a home, without land, tools, or savings, he had entered into competition with rich, landed, skilled neighbors. To be a poor man is hard, but to be a poor race in a land of dollars is the very bottom of hardship" (Du Bois 2007 [1903], p. 14). Douglas suggests that Du Bois hoped the "Talented Tenth," college educated African Americans, would constitute a vanguard of critical voices raising serious questions about the unchecked excesses of a social order where only competitive individualism and capitalist market logic were the core social values. Based on Du Bois's vision, Douglas proposes that historically Black colleges and universities today ought to be the environments from which such contemporary critiques emerge.

A racialist project such as that of Nicholas Wade rests upon the reification of ethnoracial group boundaries. Ethnoracial group boundary formation and inequalities may exist in and vary across many domains of social life. As regards the basic processes undergirding boundaries themselves, sociologist Nicholas Vargas examines the hypothesis that Latino/as may increasingly come to identify themselves as White. His work relies upon intriguing data from the 2006 Portraits of American Life Study. He shows that phenotype, social class background, and, most importantly, the extent of external social validation shape the likelihood that Latino/as will identify as White. His results raise profound questions about the speculations that Latino/as will soon move to increasing White self-identification.

In a social context long systematically structured to impose disadvantage and marginalization on some racialized groups and to privilege others, social policy interventions that aim merely at enhancing individual freedom of choice may prove less successful than hoped in reducing group inequality. Sociologist Mary Pattillo examines school choice as a strategy for improving educational outcomes for African Americans. Focusing largely on qualitative interviews with seventy-seven African American parents, guardians, and parent figures who had children entering Chicago area high schools in 2007, her results greatly problematize much of the rhetoric and presumed rationale for school choice as an option for low income Blacks. Instead of bringing 
greater empowerment, agency, and more personal control, the burdens involved with "choice" amid familial and community resource constraints worked against each of these presumed benefits of choice. The research both problematizes the case typically advanced for school choice and brings important new and richly textured data to these issues.

Location in physical and residential space is at the heart of issues of segregation versus integration. From the pioneering work of sociologists Douglas Massey and Nancy Denton (1993) we know that racial residential segregation patterns in the United States are the deliberate product of social policy action and widely dispersed and common behavioral patterns of racial discrimination. Furthermore, we know that segregation is a key component in concentrating disadvantage and structuring racial privilege and dis-privilege. Eve Garrow now poses the question of whether ethnoracial background and patterns of residential segregation play a part in the disbanding of nonprofit service providing organizations. Based on a carefully developed survey of over 600 nonprofits in Los Angeles county conducted in 2002, she can show that as the percentage of Blacks or Latinos in a neighborhood rises so does the rate of nonprofit disbanding. Conversely, the higher percentage of White residents the lower the rate of disbanding. The results thus raise powerful questions about the extent to which nonprofits can operate as bulwark against the disadvantages attendant to racial segregation and inequality as they too are subject to the same racial stratifying forces operative in society at large.

Economist Timothy Bates provides an examination of the changing landscape faced by Minority-owned Business Enterprises (MBEs). In particular, he traces the evolution of affirmative action in the market for government and corporate contracts, termed preferential procurement, and the number and success of MBEs. His results indicate that while the rules have changed over time and across locales, preferential procurement practices have been enormously important in lowering the barriers to minority business entry and long-term success. His results raise serious questions about the future of MBEs as the legal application of standards of "strict scrutiny" by the courts to preferential procurement practices intensifies and as greater discretion in the application and interpretation of procurement practices takes place.

In the wake of the murders of Walter Scott, Trayvon Martin, Michael Brown, Eric Garner and others, deep problems of systematic racial bias and anti-Black statesanctioned violence are receiving renewed scholarly attention (see essays in Johnson et al., forthcoming). Several articles in this issue tackle the ways that race, issues of crime and policing, as well as mass incarceration intertwine. One article focuses more on elite social actors within major institutions, a second examines the underpinnings of public opinion on crime-related policy questions, and a third attempts to bring broader theoretical perspective and context to the interplay of race, crime, and politics.

Distinguished sociologist John Hagan and his colleagues combine oral history, interviews, and the use of proportional hazard models to analyze state record data to develop a revealing account of the California prison boom. They challenge the view that a "prison fix" to the problem of declining agricultural land value spurred the prison building boom. Instead, they suggest that a parochial Republican movement against crime and perceptions of African American and Latino intrusion into previously comfortably White communities, when combined with novel leveraged financing methods, made the prison boom possible. The research provides remarkable multi-method data validation for a complex social process that undergirded the astonishing boom in prison building and sharply rising incarceration rates for people of color.

Political scientists David C. Wilson and his colleagues wrestle with understanding the wellsprings of public opinion on political rights for felons. They rely upon data 
from the 2010 web-based Cooperative Congressional Election Study social survey, finding that both racial resentment and political ideology influence levels of support for the political rights of ex-felons. Their results clearly show that racial prejudice is a key bulwark of the public taste for punitiveness (Bobo and Johnson, 2004). Their results add critical nuance in also showing that this is true with regard to the rights of felons, but also that the effects of prejudice function with differential potency depending on a person's political ideology. Prejudice has stronger effects among liberals than it does among conservatives, though it is important for both.

Carla Shedd provides a deeply reflective review of two new books, one on the evolution of the treatment of African Americans within the juvenile justice system and one that attempts to fashion a historically and socially grounded account of Black involvement in crime. Shedd's reflections give us new useful conceptual leverage on these issues. She brings out just how key elite institutional actors - and the political projects, frames, and rhetoric they deploy—variously engage, spark, and sometimes shape the appetites of the mass citizenry and ultimately dictate policy making outcomes. Her review essay thus stresses how these two projects—race and juvenile justice and Black law-breaking behavior-are connected by the ways in which the criminal justice system, especially the police and prison system, have long functioned as key agents in a profoundly racialized and discriminatory experiment in democracy.

Ashley Yates is right. The politics of respectability is not enough to overcome a system of multidimensional, deeply entrenched racial oppression, especially when that system evinces a clear readiness to use deadly force in its defense. We typically hope that the world of ideas and scholarship will be an arena for crafting the knowledge, perspectives, and research results that will help enfranchise and empower marginalized populations. Yet, in this moment we observe the re-cycling of crudely racist ideologies in the new garb of genomic science, the tenacity of racial boundaries and identities, and the use of the tools of government to only briefly serve a progressive agenda while at other times operating systematically to perpetuate marginalization for some and great privilege for others. In this context, we must maintain a readiness to confront and challenge the troublesome recurrences of the bacillus of racism which remain all too potent in our time.

\section{REFERENCES}

Bobo, Lawrence D. and Devon Johnson (2004). A Taste for Punishment: Black and White Americans' Views on the Death Penalty and the War on Drugs. Du Bois Review: Social Science Research on Race, 1: 151-180.

Du Bois, W. E. B. (2007 [1903]). The Souls of Black Folk. New York: Oxford University Press.

Fredrickson, George M. (2002). Racism: A Short History. Princeton, New Jersey: Princeton University Press.

Johnson, Devon, Patricia Y. Warren, and Amy Farrell (Eds.) (forthcoming). Deadly Injustice: Trayvon Martin, Race, and the Criminal fustice System. New York: New York University Press.

Massey, Douglas S. and Nancy A. Denton (1993). American Apartheid: Racial Segregation and the Making of the Underclass. Cambridge, MA: Harvard University Press.

U.S. Department of Justice (2015). Investigation of the Ferguson Police Department. Civil Rights Division. www.justice.gov/sites/default/files/opa/press-releases/attachments/2015/03/04/ ferguson_police_department_report.pdf (accessed April 12, 2015).

Wade, Nicholas (2014). A Troublesome Inheritance: Genes, Race and Human History. New York: Penguin Press. 